\title{
South Africa in the BRICS: Last But Not Least
}

\author{
V. Shubin
}

\begin{abstract}
Vladimir Shubin - Professor, principal research fellow, Institute for African Studies, Russian Academy of Sciences; PhD (Honoris Causa), University of the Western Cape, South Africa; 30/1, Spiridonovka Street, 123001 Moscow, Russian Federation; E-mail: vlgs@yandex.ru

South Africa joined BRIC group of Brazil, Russian, India and China in 2011, two years after it was established, thus creating the BRICS. This was consonant with the main principles of South Africa's foreign policy under its first democratic government. It regarded the association as a group of like-minded independent countries to be a political and moral force for changing the world. By admitting a leading African country to the group, the original BRIC members sought to eliminate the geographical divide and include the country that enjoys a high moral authority and plays important role in peacekeeping and mediating conflicts. Through its membership in the BRICS, South Africa wanted to achieve aims at various levels: addressing poverty, inequality and job creation at home; gaining synergic support from BRICS partners for Africa; and increasing support for reforming the international financial institutions and the United Nations. This article analyzes to what extent those plans have been realized during the four years of South Africa's membership in the BRICS and comes to the conclusion that South Africa is the last but not least member.
\end{abstract}

Key words: South Africa, BRICS, IBSA, foreign policy, United Nations, New Development Bank, trade, peace and security

\section{The Foundations of Foreign Policy of Democratic South Africa}

In 2014, South Africa celebrated 20 years since the end of the apartheid regime and the creation of the democratic state. One distinct feature is a foreign policy drastically different from that of the previous regime. Its key foreign policy priorities were highlighted in Nelson Mandela's [1993] article in Foreign Affairs: "the interests of the continent of Africa should be reflected in our foreign-policy choices; that economic development depends on growing regional and international economic cooperation in an interdependent world."

Since 1994, South Africa has pursued closer bilateral ties with other African countries and emphasized the developing world as a whole, that is the countries representing the global South, including those that became BRICS members.

Joining this club of strong non-western countries was in line with South Africa's foreign policy. It made an important step in this direction in June 2003, with the creation of the India-Brazil-South Africa (IBSA) Dialogue Forum. A prominent member of the South African cabinet said that Pretoria hoped China would join the group, and then, with Chinese encouragement, Russia. ${ }^{1}$

Nevertheless, in June 2009 when the first scheduled BRIC leaders' summit took place in Yekaterinburg, no South African leader was there. South Africa was disappointed and, since the meeting took place in Russia, some blamed Moscow. However, only South Africa could be held responsible. The first practical step on the road to forming the BRIC was taken in September

${ }^{1}$ Author's discussion with a member of the South African Cabinet, Pretoria, 26 April 2005. 
2006 when, on the initiative of the Russian president, the foreign ministers of Brazil, Russia, India and China met in New York during the United Nations General Assembly. In May 2009 the foreign ministers met outside New York, in Yekaterinburg. South Africa did not take part in these meetings but expressed interest in being part of the emerging group just some weeks before the first BRIC summit. ${ }^{2}$

Newly elected president Jacob Zuma and Maite Nkoana-Mashabane, his minister of international relations and cooperation, were determined that South Africa be part of the new group. In 2010, Zuma visited all four BRIC members, winning their support for South Africa's membership. Nkoane-Mashabane, soon after Yekaterinburg Summit, sent an official letter to her counterparts and then, while in Beijing, said, "if you want to build houses, you need more than one BRIC" [Cheng, 2010]. On 23 December 2010 she received a call from her Chinese colleague, who said that South Africa was officially invited to join BRIC and Zuma was to attend its next summit in Sanya, China, in April 2011.

\section{Why Did South Africa Want to Join the BRIC and Why Was It Admitted?}

Why was South Africa so eager to join the BRIC and why did its members agreed to it, given that it is much smaller in population, territory and gross domestic product (GDP)? Mandisi Mpahlwa, South Africa's ambassador to Moscow, underlined that "it was never about the size of the economies, populations or landmasses of the BRIC member countries" [Department of International Relations and Cooperation (DIRCO) of the Republic of South Africa, 2011]. He made it clear that for Tshwane (the administrative capital of South Africa) the importance of the BRIC goes beyond economics and that it was viewed as "an association of like-minded countries with a reputation for being independent and committed to reforming global decision-making structures," a political and moral force for change, that can help to create a better world.

At a "lower," regional level, South Africa is interested in strengthening cooperation between the other BRICS members and African countries. In Zuma's [2011] first speech at the Sanya Summit, he spoke about $\$ 480$ billion needed to invest in Africa's infrastructure and urged the companies from member states to collaborate with the New Partnership for Africa's Development (NEPAD).

South Africa is often called the "gateway" to the African continent, and this probably played a role in the country's admission to the BRICS. Speaking in Parliament in June 2011, Zuma referred to the BRICS membership as strengthening "our position as a gateway to Africa" [Gerrit, 2013, p. 407]. Recently, Rob Davies, minister of trade and industry, called South Africa "a driver of regional integration as well as being a major investor. It is a gateway to the region, though not a gatekeeper" [Joffe, 2015].

Prestige also played a role in South Africa's desire to join the BRIC. Zuma [2011] said: "We are now co-equal co-architects of a new equitable international system."

As to the second question of why the BRIC members agreed to accept South Africa, there were a number of reasons. South Africa was not the only country in the (informal) list of candidates, and some of them have bigger economies. For example, at that time the GDP of Indonesia was $\$ 847$ billion, Mexico's was $\$ 1.155$ billion, Turkey’s was $\$ 773$ billion, Korea’s was $\$ 1.116$ billion and South Africa's was just $\$ 408$ billion [Centre of Humanitarian Technologies, 2014].

Clearly, however, the size of GDP was not the main criterion for inviting South Africa. The desire to have members on every continent, thereby eliminating the geographical divide, was

${ }^{2}$ Author's discussion with an official of the Department of International Relations and Cooperation, Pretoria, 31 March 2012. 
more important. Nigeria, a rapidly growing competitor to South Africa, overtook South Africa in 2013 with $\$ 488$ billion GDP [Magnowski, 2014]. Instead, other criteria came into play. South Africa has excellent infrastructure that makes it a gateway to the continent, the importance of which for the global economy has been universally recognized. Also, the political instability and growing terrorist activity in Nigeria also did not play in its favour.

Furthermore, South Africa enjoys a high moral authority on the international scene, having rid itself of apartheid. Also, it plays active role in peacekeeping and mediating during various conflicts, such as its successful facilitation of the political solution to the crisis in Zimbabwe and efforts to stop the war in the Darfur region of Sudan and in South Sudan.

\section{South Africa's Goals within the BRICS}

Joining the BRICS was regarded by many in South Africa as a triumph of its foreign policy, but not by everybody, especially in the academic community. There were two other views apart from the supportive mainstream. One was negative (be it overtly or covertly). Mills Soko and Mzukisi Qobo [2011] regarded the prevailing feelings that accompanied South Africa's admission as "an affront to our national pride." This view follows Joseph S. Nye, a professor of neoliberalism in international relations and former U.S. assistant secretary of defence and chair of the U.S. National Intelligence Council, who had always been critical of the BRIC. Writing soon after the 2013 Durban Summit, he called it an "apparent success," but remained "skeptical," with his attitude clear in the title of his article - "BRICS without mortar" [Nye, 2013].

Narnia Bohler-Muller [2013, p. 368] of South Africa's Human Science Research Council wrote: "Critics have pointed out inconsistencies in South Africa's foreign policy engagement and have raised questions about its membership with BRICS that is seen to be compromising South Africa's commitment to international human rights laws. As trade-offs are made for the sake of economic growth and development." However, the reality was the opposite: as the only BRICS member to support the notorious UN Security Council (UNSC) Resolution 1973, South Africa facilitated (although of course unintentionally) gross violations of human rights during the North Atlantic Treaty Organization's aggression in Libya that continue up to the present.

Critics reflected the position of those in South Africa who do not want it to be closer to the "non-western world." However, all the BRICS members aspire to have good relationships with the West (even relationships are sometimes strained, such as in Russia's case now), and Tshwane's membership did not interfere with this vector of its foreign policy. In this regard, the discussion document drafted by the Department of International Relations and Cooperation (DIRCO) states: "South Africa will continue to pursue strategic partnerships with the North ... to mobilise support for Africa's development" [Gerrit, 2013, p. 413]. Zuma [2015] confirmed this approach in his 2015 State of the Nation Address: "countries of the developed North remain important strategic partners for South Africa through which the country is able to advance its national and foreign policy."

On the other hand, the criticism of the BRICS continues to be hear from the left or leftist part of the South African political spectrum, where the group is considered "sub-imperialist" [Bond, 2013a, p. 1]. Patrick Bond [2013b, p. 2] of the University of KwaZulu-Natal writes about South African "deputy sheriff” duty within BRICS.

\section{How South Africa Foreign Policy Works in Relation to the BRICS}

South African academic research on the BRICS is coordinated by the state-funded Human Science Research Council (HSRC). On the eve of the Durban Summit in 2013, the government designated the HSRC the incubator of the South African BRICS Think Tank supported 
by DIRCO and the Department of Higher Education and Training. Since South Africa held the BRICS presidency for 2013/14, its think tank was responsible for the agenda of the BRICS Think Tanks Council, particularly for coordinating the drafting of a long-term vision and strategy for the BRICS. Brazil inherited this role for the Fortaleza Summit in 2014, and South African academics continue to play an active role in it.

In 2013, HSRC incorporated the Africa Institute for South Africa (AISA), which was instrumental in publishing a mammoth 447-page book, Laying the BRICS of a New Global Order: From Yekaterinburg 2009 to eThekwini 2013, with contributions by researchers from all five member states, including five Russian academics [Kornegay and Bohler-Muller, 2013]. Besides AISA and HSRC, a number of other South African think tanks are doing research on the BRICS, including the South African Institute of International Affairs (SAIIA) and the Consumer Unity and Trust Society (CUTS) International that, on the eve of the Durban Summit, issued The BRICS and the New World Order: A Beginner's Guide [Singh and Dube, 2013]. The Centre for Conflict Resolution organized a policy advisory group seminar on "South Africa and the BRICS: Progress, Problems, and Prospects" in August 2014 [Centre for Conflict Resolution, 2014]. ${ }^{3}$

Unlike in most other BRICS members, South Africa's parliament plays a greater role in foreign policy, in particular its portfolio committees on foreign affairs and on trade and industry. Both executive and legislative branches in South Africa actively project the BRICS as essential for the country. In particular, DIRCO and its head Maite Nkoana-Mashabane, the Ministry of Trade and Industry and its head Rob Davies, as well as other government bodies, do their best to project the benefits of BRICS membership for South Africa.

For example, at the meeting organized by business associations, Richard Vries, CEO of Gibb, "described the challenge that construction firms faced in competing with South Africa's giant BRIC partners for infrastructure contracts in Africa" [Fabricius, 2013]. He reflected the views of those who worry that by joining the BRICS and facilitating the entry of the other four members into Africa, South Africa is creating competition for itself. In response, NkoanaMashabane told business leaders that instead of focusing on the challenges of competing with the other BRICS members they should seize the opportunity presented by South Africa's membership because "the time was past for assessing the virtues of being a member" [Fabricius, 2013]. She said that "I want us to spend more time, not listing challenges, but talking about how we can get the most out of BRICS" and that business should "not spend so much time talking about our smallness."

DIRCO's [2014b] official statement names the following (rather ambitious) goals:

"South Africa seeks to achieve through BRICS, among other things:

- "At domestic level: addressing poverty, inequality and job creation.

- "At a regional level: gaining tacit support from BRICS partners ... for the promotion of the African Agenda and to ensure synergy among BRICS partners, as far as feasible, regarding their engagement with Africa.

- "At an international level: to obtain increased support for the reform of International Financial Institutions (IFIs), the revival of the Doha Development Agenda, as well as the reform of the United Nations (UN) including the United Nations Security Council (UNSC)."

It also expects that the BRICS-Africa cooperation "will support Africa's efforts to diversify and modernize its economies through infrastructure development, knowledge exchange, increased access to technology, enhanced capacity-building and investment in human capital" [DIRCO, 2014b].

${ }^{3}$ The author took part in this seminar and this article benefited from the seminar report and deliberations. 


\section{To What Extent Have the Hopes of South Africa Been Realized?}

During the first four years of its membership, South Africa proved to be an integral part of the BRICS and not a second-class member. It hosted the fifth BRICS summit on 26 and 27 March 2013 in Durban, or eThekwini because the old city had become a part of municipality with a new name.

Unfortunately, this summit was not adequately covered in the Russian media, which concentrated on misunderstandings between the local police and the Russian president's security detail at the expense of more important issues. ${ }^{4}$

South Africa's BRICS experts believe that the summit helped broaden the country's focus from mainly economic cooperation to development cooperation [Centre for Conflict Resolution, 2014, p. 9]. The five leaders established BRICS Business Council, composed of prominent entrepreneurs from each country and committed support to African infrastructure projects, as proclaimed in the eThekwini Declaration and Action Plan [BRICS, 2013].

In addition, as a supporting event for the fifth summit, a session of the BRICS Business Forum, established in 2010, was held on 26 March 2013 in Durban, and industry leaders from all five business communities took part [BRICS Business Forum, 2013].

Another important decision was the establishment of the BRICS Think Tanks Council, uniting research institutions of the five countries to provide critical analysis and policy advice to BRICS leaders.

The summit's main theme, suggested by Tshwane, was "BRICS and Africa: Partnership for Development, Integration and Industrialisation." In addition to discussion on the subject between the leaders of five states, South Africa organized a "retreat," with the participation of heads of African continental and regional organizations. This demonstrated its claim to be a leading country of the continent, even if not everybody in Africa agrees.

South Africa's membership in the BRICS offers it an opportunity to deepen and broaden its bilateral engagement with the other four members, even if "South Africa's private sector business as well as academia - has maintained a focus on developing external relations with partners in Europe and the United States" [Centre for Conflict Resolution, 2014, p. 16].

India and South Africa have historical ties. Both are former colonies of Britain, which contributed to the emergence of a large Indian diaspora in South Africa that now numbers about 1.3 million people. Mahatma Gandhi began his political career in South Africa, and the Indian National Congress subsequently influenced the creation of the African National Congress (ANC). India has actively supported the ANC and, in 1967, there was the ANC office in New Delhi. The first head of that office was the future South African foreign minister Alfred Nzo.

Contemporary South Africa-India relations are regarded as strategic partnership, established in March 1997. In addtion to strong political ties, trade and commerce have grown steadily. Bilateral trade is growing $30 \%$ a year. However, Tshwane's trade imbalance with New Delhi grew in the latter's favour from about R4 billion in 2011 to R23 billion in 2013 [Centre for Conflict Resolution, 2014, p. 13].

Apart from the BRICS, a new collaborative group is the Indian Ocean Rim Association [2015], previously known as the Indian Ocean Rim Association for Regional Cooperation.

More controversial is the history of South Africa's relations with China. The ANC established links with the People's Republic of China in the 1950s; however, in an environment of

4 However, according to Vyacheslav Nikonov it is not right to speak about "our mass media," because $62 \%$ of Russian media outlets belong to non-Russian citizens and therefore are vulnerable to any trends that may be contrary to Russia's national interests [Barshchevsky, 2012]. That is also true in respect of the coverage of BRICS. 
growing Sino-Soviet differences, Beijing, believing the ANC too close to its rival, froze its relations with the organization for two decades. These circumstances delayed the establishment of diplomatic relations with Beijing for a long time. The new ANC-led government inherited close ties with Taiwan and kept them until January 1998. However, China became South Africa's biggest bilateral commercial partner. Trade turnover has been growing significantly annually, and South Africa accounted for 31\% of China's trade with the African continent in 2013 [Olsen, 2013]. However, South Africa has a high trade deficit with China, which stood at about R39 billion in 2013 [Centre for Conflict Resolution, 2014, p. 13]. South Africa exports mostly primary products to China and imports manufactured goods.

A feature of South African-Sino relations is the number of high-level visits. South Africa's entry into the BRIC group was discussed and determined during Jacob Zuma's trip to China in August 2010, when the Beijing Declaration on the Establishment of a Comprehensive Strategic Partnership Between the People's Republic of China and the Republic of South Africa and a number of other bilateral agreements were signed. The following year, in September 2011, South African deputy president Khalema Motlanthe led a trade delegation to Beijing. During that visit, the China Development Bank and the Development Bank of South Africa signed a \$2.5 billion agreement. The two countries also signed a memorandum of understanding on geological exploration and mineral resources [2point6billion.com, 2011]. In July 2012, Zuma led a South African delegation that included Maite Nkoana-Mashabane and Rob Davies, as well as Collins Chabane, minister in the presidency, to the fifth Forum on China-Africa Cooperation (FOCAC) in Beijing [SAPA, 2012].

In December 2014, Zuma went to China with government ministers and 100 South African business representatives. Speaking at Tsinghua University, he emphasized that China helped his country "to belong to the BRICS family" and that South Africa counts "on this formidable friendship, including within the south and BRICS framework, as we deepen our relations and forge ahead with our developmental agenda" [Zuma, 2014a], He praised the role of China in Africa: "The emergence of China as a power among others gives or offers an opportunity to African countries to be able to free themselves from the shackles that are really colonially designed" [Agence France Presse, 2014].

Frameworks for cooperation between the two countries have recently been established, for example the Bi-national Commission involving seven sector-specific subcommittees (diplomacy, economy and trade, science and technology, education, energy, minerals, and defence), the Interministerial Joint Working Group and the Five- to Ten-Year Framework on Cooperation. During Zuma's 2014 visit, China declared that it was ready to invest in and work with South Africa in sectors such as infrastructure development, ocean and green economies, science and technology, agriculture, environment, and finance [DIRCO, 2014a].

One of the themes of Zuma's discussion in Beijing was the BRICS New Development Bank (NDB), and both parties agreed on its establishment and operationalization as soon as possible. Addressing the South Africa-China Business Forum, Zuma said: "South Africa is keen to ensure that the Bank's African Regional Centre [to be established in South Africa] provides further impetus to the strategic relationship that was forged between the BRICS and African leadership in 2013 in Durban, to enhance economic development for the continent. We will cooperate with China to ensure that the Shanghai Headquarters and the African Regional Centre in South Africa are established as per agreed timelines. We have prioritised the ratification of the agreement establishing the Bank. South Africa has also instituted committees to make the African Regional Centre operational" [SA News, 2014c].

Tourism is an important part of the South African and the importance of China to this sector is growing: the number of tourists from China more than doubled between 2010 and 
2013, from 68,000 to 152,000 [South African Tourism, 2012, p. 18; 2014, p. 11]. Four Confucius Institutes had been established in South Africa by 2014 to promote cultural and educational ties between the two countries.

The history of South Africa's relations with Russia is well known and an analysis of its current stage would require a separate article. South Africa's accession to BRICS, no doubt, enhanced the relationship. Putin's participation in the Durban Summit was followed by bilateral talks with Zuma. Although the first meeting was short, just a couple of hours, Putin and Zuma signed the Joint Declaration on the Establishment of a Comprehensive Strategic Partnership that outlined the terms for bilateral cooperation in areas including trade, investment and humanitarian intervention.

In May 2013, Zuma visited Sochi, and in August 2014 he visted Moscow. In September 2014, a bilateral framework agreement on strategic cooperation in the nuclear field was signed by South Africa and Russia.

However, commercial and cultural ties between South Africa and Russia are weak compared to excellent relations in the political sphere. The development of these ties is not helped by a distorted picture of Russia often painted by South African media and some academics. For example, Gerrit Olivier [2013, p. 411], a former diplomatic representative of the "old" Pretoria regime sent to Moscow. regards Russia as a variation "of non-democratic authoritarian regimes."

Relations between South Africa and Brazil were actively developed in 2003 after Luiz Inácio Lula da Silva came to power. Lula, who was in office from 2003 to 2011, played a key role with South Africa's Thabo Mbeki in founding the IBSA Dialogue Forum. Brazil is South Africa's largest trading partner in Latin America; trade is growing, and in 2013 was R21 billion [Centre for Conflict Resolution, 2014, p. 15]. However, relations were marred by a dispute initiated in 2012 by Brasília at the World Trade Organization [(WTO), 2012] following the imposition of anti-dumping duties by South Africa on imports of Brazilian poultry, but fortunately it was resolved within the framework of the WTO.

A number of Brazilian firms maintain offices in South Africa, which serve mainly as headquarters for their operations in other African countries [Centre for Conflict Resolution, 2014, p. 15]. Emerging areas of cooperation between South Africa and Brazil include, for example, nuclear technology and the defence industry. In particular, A-Darter air-to-air missile is being developed by South Africa's Denel in collaboration with Brazil [Centre for Conflict Resolution, 2014, p. 16].

Lula's successor, Dilma Rousseff, visited South Africa in November 2011 to take part in the fifth IBSA Summit and then again in March 2013 for the BRICS summit. Zuma participated in the next BRICS summit in July 2014 in Fortaleza.

After the 2013 Durban Summit, South Africa passed the chair to Brazil for the 2014 Fortaleza Summit. South Africa's presidency shows that the country had "fully implemented" the eThekwini Action Plan [DIRCO, 2014b]. In particular, it hosted several meetings of high-level officials, such as the BRICS national security advisors, and of the ministers responsible for trade, finance, agriculture, education, health, social security, and science, technology and innovation.

Since the creation of the BRICS five years ago, intra-BRICS cooperation has been expanding and it now includes more than 30 issue areas ranging from health and education to science and technology. However, at least for South Africa, the finance and trade agenda remains the most important. Having returned from the summit in Brazil, Zuma hailed the establishment of the NDB as "an everlasting legacy that will change the face of global economics and the face of all the developing world for better" [SA News, 2014a]. 
Tshwane was satisfied with the decision that the five founding countries equal contribute equally to the bank's initial subscription of $\$ 50$ billion. Although it did not succeed in its hopes to host the bank's headquarters, the first regional office will open in Johannesburg.

South African analysts believe that the NDB has the potential to be an alternative to the World Bank for funding critical infrastructure projects. Trade and industry minister Rob Davies made it clear in his statement on the eve of the Fortaleza Summit: "On the African continent, [the NDB] can certainly play a very important role in funding infrastructure projects across the continent. I think particularly those that link up different countries from the African continent and support regional integration" [SABC, 2014].

Those analysts emphasize that the infrastructure gap (the difference between demand for infrastructure and investment levels) is estimated to be about $\$ 35$ billion in Africa, and are worried as to whether the NDB will become operational by 2016 as planned, as its initial $\$ 50$ billion capital base has to be accumulated over seven years, with each BRICS member paying $20 \%$ of its contribution ( $\$ 2$ billion) in pre-agreed instalments during this period, while the remaining $80 \%$ ( $\$ 8$ billion) is to be callable capital (pledged funds that will be provided if needed) [Centre for Conflict Resolution, 2014, p. 18].

South Africian academia and media are discussing as to what extent the NDB can have a concrete impact on transforming development cooperation by developing "a more concrete alternative strategy to challenge the dominance of the World Bank's approach" to development issues [Centre for Conflict Resolution, 2014, p. 19]. Greater internal cohesion is needed, as demonstrated by the fact that "five BRICS countries were unable to unite behind a common candidate to fill the top posts at the International Monetary Fund and the World Bank" [Centre for Conflict Resolution, 2014, p. 19].

South Africa supported the creation of the BRICS Contingency Reserve Arrangement (CRA), finalized at Fortaleza. However, the CRA will have only $\$ 100$ billion in reserves in comparison with the International Monetary Fund's (IMF) $\$ 806$ billion in reserves, while BRICS members collectively have about $\$ 5.2$ trillion in foreign currency reserves [Stuenkel, 2013].

There has been remarkable progress in boosting intra-BRICS trade. According to South Africa's statistics its total trade with the BRICS countries stood at R380.4 billion in 2013, which is $27.5 \%$ higher than the 2012 figure of R298.2 billion. Total trade with India grew substantially from R68.3 billion in 2012 to R80.8 billion in 2013, a growth of $18.3 \%$. China remains South Africa's largest bilateral trading partner, with total trade expanding from R204.6 billion in 2012 to R270.1 billion in 2013, a growth of $32.01 \%$. Total trade with Russia increased from R5.1 billion in 2012 to R7.5 billion in 2013, a growth of 47.06\%, and with Brazil, trade grew from R20.1 billion in 2012 to R21.8 billion in 2013, a growth of 8.46\% [SA News, 2014b].

South Africa expects more efficiency from the structures created by the BRICS in these fields. Zuma [2014b] said in his 2014 State of the Nation address "We will continue to deepen economic development, trade, and investment partnerships with the BRICS through the work of the BRICS Contact Group for Economic and Trade Issues." Before the Fortaleza Summit, the contact group presented the trade ministers with recommendations on increasing valueadded exports in intra-BRICS trade. The recommendations were based on a joint study conducted under South Africa's 2013-2014 chair of the BRICS bloc. The trade ministers [2014] meeting welcomed the study, but "instructed the [contact group] to continue working on its recommendations."

Another important aspect of South Africa's BRICS membership is strengthening the group's stand on peace and security matters. The issue of defence has not been highlighted in the BRICS documents (apart from the meetings of officials responsible for security matters), but its potential importance can not be overestimated and South African researchers appreciate it. Anton Kruger [2011] noted that South Africa needed to increase defence spending to be on 
an equal footing with the other BRICS members. Along with South Africa's commitments on peacekeeping through African Union, he emphasized its unique location "on the 3 essential shipping routes from West to the East." In his opinion, this fact and the resources of South Africa "will allow BRIC to better compete with the G7 in global issues."

Currently, the attention of South African analysts is drawn to the UN and the role of BRICS members in it. In 2011, there was a unique situation when Russia and China, the two permanent members of the UNSC, were joined by South Africa, India and Brazil. However, this opportunity to collaborate on issues on the international security agenda and to challenge the dominance of the UNSC by the U.S., France and Britain was missed. The response of the BRICS countries to the crises facing the UNSC in 2011, particularly over Libya, raised serious questions about their ability to craft cohesive foreign policy positions.

It is admitted in South Africa (even informally by the government officials) that South Africa made a mistake voting for UNSC Resolution 1973, authorizing intervention in Libya, just it is admitted in Russia (again mostly informally) that then Dmitry Medvedev made a similar mistake by not using Russia's veto. Ebrahim I. Ebrahim [2011], South Africa's deputy minister for international relations and co-operation, stated that "many countries, including South Africa, feel betrayed by Western powers on resolution 1973."

The way in which Resolution 1973 was implemented and regime change policy of the North Atlantic Treaty Organization (NATO) left the South African government feeling betrayed by the United Kingdom, France and the United States, and this sense of betrayal might prevent South Africa from supporting other UN resolutions proposed by these countries.

There are differences also within the BRICS bloc on the issue of the responsibility to protect (R2P). In particular, although South Africa is prepared to support the concept (it was included, in different words, in the Constitutive Act of the African Union), China and India are strong supporters of the principle of non-intervention and oppose external military interventions. Brazil has proposed the new, very interesting concept of the "responsibility while protecting” (RwP), which South Africa supported [Centre for Conflict Resolution, 2014, p. 3].

Criticism of R2P grew in South Africa after so-called mission creep in Libya in 2011 when NATO abused Resolution 1973 to pursue a regime change agenda against Muammar Qaddafi [Centre for Conflict Resolution, 2014, p. 21]. South Africa, Brazil, China and India opposed the introduction of sanctions on Russia in 2014. This was regarded in South Africa as "an ability to forge cohesion in resistance to Western hostility towards one of their own members" [Centre for Conflict Resolution, 2014, p. 22].

In the Fortaleza Declaration, South Africa with the other BRICS members made clear "the necessity to promote, protect and fulfill human rights in a non-selective, non-politicized and constructive manner, and without double standards" [BRICS, 2014].

South Africa actively participates in peacekeeping operations in Africa. Given the delays in creating the African Stand-by Force, since 2013 South Africa has been involved in the creation of the African Capacity for Immediate Response to Crises (ACIRC) as a temporary solution. During Zuma's visit to Beijing in 2014, "President Xi Jinping declared that China was prepared to assist the African Union in its peacekeeping missions and was ready to discharge resources to the continent's peacekeeping mechanisms particularly the African rapid response forces" [DIRCO, 2014a].

South Africa, like other BRICS members, fully understands that it is impossible "to create a better world" (to borrow words from Ambassador Mpalhwa) without reforming "Westerndominated institutions of global governance" even if they "do not necessarily agree on how the architecture of global governance should be reshaped" [Centre for Conflict Resolution, 2014, p. 24]. One broad issue hotly debated in South Africa is whether BRICS members "are status quo powers, or revisionist actors with a transformative vision for an alternative world order," or 
even "a third and far more critical view regards the BRICS countries as a group of 'sub-imperialist' collaborators within the Western-dominated system" [Centre for Conflict Resolution, 2014, p. 24].

As mentioned above, BRICS countries were divided on the issue of the election of the IMF and World Bank top officials. In relation to the IMF, in 2011 South Africa opposed the appointment of managing director on the basis of nationality (a French woman succeeded a French man), and in the case of the World Bank, in 2012 South Africa and Brazil unsuccessfully supported Nigeria's finance minister, Ngozi Okonjo-Iweala, while Russia openly, and China and India more discreetly, backed the winning candidate - the American Jim Yong Kim. There was more cohesion in 2013, when Roberto Azevêdo, Brazil's ambassador to the World Trade Organization, was elected its director general.

While the creation of the NDB and the CRA were welcome in South Africa, many observers doubt their ability to reduce dependence on the World Bank and the IMF. The fact that the CRA allows member countries to borrow only $30 \%$ of their quota (which is just $\$ 3$ billion in the case of South Africa) and then they must turn to the IMF is particularly criticized [Centre for Conflict Resolution, 2014, p. 25].

Both government and civil society in South Africa are unhappy with the very slow rate of the UN reform, especially that of the Security Council. South Africa seeks a permanent seat, as do India and Brazil, but their plans differ on how to achieve this goal. India and Brazil, along with Germany and Japan, have formed the so-called Group of Four in mutual support of their candidacies, but South Africa is bound by the Ezulwini Consensus, reached by African countries in 2005, and must therefore favour the unrealistic demands by two African permanent members with veto power, although now, along with Nigeria, South Africa prefers dropping the African insistence on the veto [Centre for Conflict Resolution, 2014, p. 26-27].

One more issue widely discussed in South Africa with respect to the BRICS is that of the relationship with IBSA. When South Africa was invited to join the BRIC, Nkoane-Mashabane said: "We believe that the IBSA will get a better balance, and become even stronger, with South Africa now as a member of the BRICS. We remain convinced that South Africa's diversified foreign policy objectives and interests allow for both groupings (IBSA and BRICS) to co-exist. It is our belief that the mandates of BRICS and IBSA are highly complementary" [DIRCO, 2010].

However, not everybody, both in South Africa and elsewhere, is so sure. There is a tendency to justapose the three IBSA members with "common democratic credentials" against "authoritarian" China and Russia. More signifiantly, the older organization provides "a framework for cooperation among its three members in a range of sectors, from health and education to defence." ${ }^{5}$ However, the expansion of sectoral cooperation among the BRICS members means a certain duplication and increases the chance of IBSA's demise. Nevertheless, the dominant view in South Africa is still that the BRICS and IBSA do not exist in opposition to each other but are complementary.

When discussing the prospects of BRICS, South African scholars speak about the need for the NDB, "in contrast to the Bretton Woods institutions," to retain its commitment "to non-conditionality and non-interference in the policymaking space of borrowing countries" [Centre for Conflict Resolution, 2014, p. 33]. Another recommendation is to open up BRICS engagement with non-governmental organizations, beyond the BRICS Think Tanks, to influence western-dominated debates on development, climate change and human rights. In this respect, the Congress of South African Trade Unions (COSATU), the country's biggest federa-

${ }^{5}$ Author's notes of presentations made by Harihara S. Viswanathan and Chris Landsberg at the Centre for Conflict Resolution policy advisory group seminar, Tshwane, 30-31 August 2014. 
tion of trade unions, takes an active (and realistic) position on South Africa's membership in BRICS. It noted: "On the one hand, the rise of BRICS has the potential to tip the balance of forces more towards the South ... However, at the same time, it has facilitated the outwards expansion of multinationals based in those countries. These realities prompt a deeper discussion about our understanding of the architecture of imperialism, particularly in light of South African capital on the African continent" [COSATU, 2012, p. 10]. South Africa hosted the second BRICS Trade Union Forum in Durban in March 2013 [BRICS Trade Union Forum, 2013].

\section{BRICS Challenges}

It is true that South Africa was a latecomer to the BRICS, but the expression "last but not least" characterizes its role in the bloc. That has been proved not only by a successful hosting of the Durban Summit, but also by activities of South African governmental, academic, business and other organizations.

It would be wrong, however, to anticipate immediate tangible benefits of South Africa's membership in the BRICS. The development of sectoral cooperation and, in particular, the establishment and operationalization of the BRICS financial institutions takes time and effort. So far, five countries managed to overcome any existing and arising contradictions among themselves and to find a common approach to major political and economic problems. An important side effect of South Africa's membership is the strengthening of its relations with four prominent countries that lead in their respective regions.

South Africa is actively involved in the preparation of the seventh BRICS Summit hosted by Russia in July 2015, and there are good reasons to expect it will be a valuable contributor to discussions and decision making in Ufa.

\section{References}

2point6billion.com (2011) "China looking to enhance ties with South Africa." Available at: http:// www.2point6billion.com/news/2011/10/03/china-looking-to-enhance-ties-with-south-africa-10252.html (accessed 25 May 2015).

Agence France Presse (2014) South Africa's Zuma calls China an anti-colonial force. 5 December. Available at: http://www.africadaily.net/reports/South_Africas_Zuma_calls_China_an_anti-colonial_force_999.html (accessed 25 May 2015).

Barshchevsky M. (2012) "Vybor posle vyborov.” ["Election after elections.”] Rossiyskoy gazety, 22 March. Available at: http://www.rg.ru/2012/03/22/vybor.html (accessed 25 May 2015).

Bohler-Muller N. (2013) South Africa's Pretoria agenda: the role of state, sovereignty, non-intervention and human rights within the context of emerging power multi-lateralism. In: F. Kornegay and N. Bohler-Muller, eds., Laying the BRICS of a new global order: from Yekaterinburg 2009 to eThekwini 2013. Pretoria: Africa Institute of South Africa, pp. 368-82.

Bond P. (2013a) So, are BRICS 'sub-imperialists'? Lins International Journal of Socialist Renewal, 29 March. Available at: http://links.org.au/node/3265 (accessed 25 May 2015).

Bond P. (2013b) Subimperialism as lubricant of neoliberalism: South African "deputy sheriff" duty within BRICS. Presentation at the Global Studies conference, University of California Santa Barbara, 23 February. Santa Barbara CA.

BRICS (2013) "BRICS and Africa: partnership for development, integration and industralisation.” eThekwini Declaration, Durban, 27 March. Available at: http://www.brics.utoronto.ca/docs/130327-statement.html (accessed 25 May 2015).

BRICS (2014) “The 6th BRICS summit: Fortaleza declaration.” Fortaleza, Brazil, 15 July. Available at: http:// www.brics.utoronto.ca/docs/140715-leaders.html (accessed 25 May 2015). 
BRICS Trade Ministers (2014) "The 4th meeting of the BRICS trade ministers: joint communiqué.” Fortaleza, Brazil, 14 July. Available at: http://www.brics.utoronto.ca/docs/140714-trade.html (accessed 25 May 2015).

BRICS Trade Union Forum (2013) "Declaration of the second BRICS Trade Union Forum." Durban, 25 March. Available at: http://www.cosatu.org.za/show.php?ID=7103 (accessed 25 May 2015).

Centre for Conflict Resolution (2014) South Africa and the BRICS: progress, problems and prospects. November. Pretoria. Available at: http://bricspolicycenter.org/homolog/arquivos/Relatorio.pdf (accessed 25 May 2015).

Centre of Humanitarian Technologies (2014) "Reyting stran mira po urovnyu valovogo vnutrennego produkta." ["Ranking of countries by gross domestic product."] Moscow. Available at: http://gtmarket.ru/ratings/ratingcountries-gdp/rating-countries-gdp-info (accessed 25 May 2015).

Cheng G. (2010) Visiting minister makes case for South Africa to join 'BRIC'. China Daily, 27 February. Available at: http://www.chinadaily.com.cn/cndy/2010-02/27/content_9512440.htm (accessed 25 May 2015).

COSATU (2012) International policy. Adopted by the 11th National Congress of COSATU, September. Available at: http://www.cosatu.org.za/docs/policy/2012/internationalpolicy.pdf (accessed 25 May 2015).

Department of International Relations and Cooperation of the Republic of South Africa (2010) "Minister Nkoana-Mashabane on SA full membership of BRICS." Pretoria, 24 December. Available at: http://www.dfa. gov.za/docs/2010/brics1224.html (accessed 25 May 2015).

Department of International Relations and Cooperation of the Republic of South Africa (2011) "Statement by Ambassador Mandisi Mpahlwa of South Africa, Peoples' Friendship University, Moscow.” 18 May. Available at: http://www.dfa.gov.za/docs/speeches/2011/mpah0518.html (accessed 25 May 2015).

Department of International Relations and Cooperation of the Republic of South Africa (2014a) "Media statement: President Zuma lauds China visit.” Pretoria, 6 December. Available at: http://www.dfa.gov.za/ docs/2014/chin1208.html (accessed 25 May 2015).

Department of International Relations and Cooperation of the Republic of South Africa (2014b) "President Zuma arrives in Fortaleza, Brazil for the BRICS summit." Fortaleza, Brazil, 14 July. Available at: http://www. dfa.gov.za/docs/2014/brics0714.html (accessed 25 May 2015).

Ebrahim E. I. (2011) "Lecture by Deputy Minister of International Relations and Cooperation, Ebrahim I Ebrahim, on the occasion of the Speakers Meeting at the South African Institute of International Affairs." Department of International Relations and Cooperation of the Republic of South Africa, 22 July. Available at: http://www.dfa.gov.za/docs/speeches/2011/ebra0722.html (accessed 25 May 2015).

Fabricius P. (2013) "BRICS: minister scolds small-time business.” South African Foreign Policy Initiative, 18 March. Available at: http://www.safpi.org/news/article/2013/brics-minister-scolds-small-time-business (accessed 25 May 2015).

Gerrit O. (2013) South Africa within BRICS: substance or piggybacking? In: F. Kornegay and N. BohlerMuller, eds., Laying the BRICS of a new global order: from Yekaterinburg 2009 to eThekwini 2013. Pretoria: Africa Institute of South Africa, pp. 399-417.

Indian Ocean Rim Association (2015) "Priority areas.” Ebene, Mauritius. Available at: http://www.iora.net/ about-us/priority-areas.aspx (accessed 25 May 2015).

Joffe H. (2015) World Economic Forum: SA' team effort. Financial Mail, 29 January. Available at: http://www. financialmail.co.za/features/2015/01/29/world-economic-forum-sas-team-effort (accessed 25 May 2015).

Kornegay F. and N. Bohler-Muller, eds. (2013) Laying the BRICS of a new global order: from Yekaterinburg 2009 to eThekwini 2013. Pretoria: Africa Institute of South Africa.

Kruger A. (2011) “From BRIC to BRICS and South Africa's military.” Institute for Security Studies, Pretoria, 27 May. Available at: http://www.issafrica.org/iss-today/from-bric-to-brics-and-south-africas-military (accessed 25 May 2015).

Magnowski D. (2014) Nigerian economy overtakes South Africa's on rebased GDP. Bloomberg, 7 April. Available at: http://www.bloomberg.com/news/articles/2014-04-06/nigerian-economy-overtakes-southafrica-s-on-rebased-gdp (accessed 25 May 2015). 
Mandela N. (1993) South Africa's future foreign policy. Foreign Affairs 72(5), p 86+. Available at: https://www. foreignaffairs.com/articles/south-africa/1993-12-01/south-africas-future-foreign-policy (accessed 25 May 2015).

Nye J. (2013) "BRICS without mortar.” Project Syndicate, 3 April. Available at: http://www.project-syndicate. org/commentary/why-brics-will-not-work-by-joseph-s--nye (accessed 25 May 2015).

Olsen K. (2013) New leader's African trip highlights China's influence on continent. Business Day, 24 March. Available at: http://www.bdlive.co.za/africa/africanbusiness/2013/03/21/new-leaders-african-trip-highlightschinas-influence-on-continent (accessed 25 May 2015).

SA News (2014a) "BRICS development bank to change global economics." South African Government News Agency, Pretoria, 17 July. Available at: http://sanews.gov.za/south-africa/brics-development-bank-changeglobal-economics (accessed 25 May 2015).

SA News (2014b) "Pres Zuma in Fortaleza for BRICS summit.” Pretoria, 14 July. Available at: http://www. sanews.gov.za/south-africa/pres-zuma-fortaleza-brics-summit (accessed 25 May 2015).

SA News (2014c) "President Zuma lauds China visit.” Pretoria, 7 December. Available at: http://www.sanews. gov.za/south-africa/president-zuma-lauds-china-visit (accessed 25 May 2015).

SABC (2014) Zuma arrives in Fortaleza ahead of BRICS summit. South African Broadcasting Corporation, 14 July. Available at: http://www.sabc.co.za/news/a/c96c2f8044b9d52b9ec4ff3bfe17c0b1/Zuma-arrives-inFortaleza-ahead-of-BRICS-20141407 (accessed 25 May 2015).

SAPA (2012) Zuma jets off to China for partnership talks. Mail and Guardian, 18 July. Available at: http:// mg.co.za/article/2012-07-18-59-zuma-jets-off-to-china (accessed 25 May 2015).

Singh S.P. and M. Dube (2013) The BRICS and the new world order: a beginner's guide. Pretoria: South African Institute of International Affairs and CUTS international. Available at: http://www.gegafrica.org/doc download/2-the-brics-and-the-new-world-order-a-beginner-s-guide (accessed 25 May 2015).

Soko M. and M. Qobo (2011) Creating more walls than Brics. Mail and Guardian, 11 January. Available at: http://mg.co.za/article/2011-01-07-creating-more-walls-than-brics (accessed 25 May 2015).

South African Tourism (2012) "2011 Annual Tourism Performance Report.” South African Tourism Strategic Research Unit, June. Available at: http://www.southafrica.net/uploads/legacy/1/528609/2011_Annual_ Report_v9_06072012.pdf (accessed 25 May 2015).

South African Tourism (2014) "2013 Annual Tourism Performance Report.” South African Tourism Strategic Research Unit, September. Available at: http://www.southafrica.net/uploads/files/2013_Annual_Report_ v8_01102014_(1).pdf (accessed 25 May 2015).

Stuenkel O. (2013). Does intra-BRICS cooperation make sense? The case of public health. Post-Western World [blog], 27 May. Available at: http://www.postwesternworld.com/2013/05/27/does-intra-brics-cooperationmake-sense-the-case-of-public-health (accessed 26 November 2014).

World Trade Organization (2012) "South Africa: anti-dumping duties on frozen meet of fowls from Brazil." Dispute no. DS439, Geneva, 27 June. Available at: https://www.wto.org/english/tratop_e/dispu_e/cases_e/ ds439_e.htm (accessed 25 May 2015).

Zuma J. (2011) "Address by President Jacob Zuma to the plenary of the third BRICS leaders meeting." Department of International Relations and Cooperation of the Republic of South Africa, Sanya, 14 April. Available at: http://www.dirco.gov.za/docs/speeches/2011/jzuma0414a.html (accessed 25 May 2015).

Zuma J. (2014a) "Lecture by President Zuma at Tsinghua University on the occasion of the state visit to the People's Republic of China." Department of International Relations and Cooperation of the Republic of South Africa, Beijing, 5 December. Available at: http://www.dfa.gov.za/docs/speeches/2014/jzum1205a.html (accessed 25 May 2015).

Zuma J. (2014b) "State of the nation address." Cape Town, 17 June. Available at: http://www.thepresidency. gov.za/pebble.asp?relid=17570 (accessed 25 May 2015).

Zuma J. (2015) "State of the nation address." Cape Town, 12 February. Available at: http://www.gov.za/ president-jacob-zuma-state-nation-address-2015 (accessed 25 May 2015). 